\title{
Climate Variability and Consequences for Crime, Insurgency in North East Nigeria
}

Bonaventure N. Nwokeoma

\author{
PhD (Criminology, Criminal Justice), Department of Sociology/Anthropology, University of Nigeria, Nsukka Nigeria
}

Amadi Kingsley Chinedu

Department of Sociology/Anthropolpgy, University of Nigeria, Nsukka Nigeria

\author{
Doi:10.5901/mjss.2017.v8n3p171
}

\begin{abstract}
Climate change discussion has primarily focused on the physical manifestation, mitigation, adaptation and finance issues. However, little attention is given to the social consequences of climate change impact especially its relationship to crime in society. Specifically, little or no research has been focused on its impact on crime, especially in developing societies. This study which examined the impact of climate change and its consequences on crime specifically terrorist activities in the Northeast of Nigeria is an effort to fill this research gap. The study adopted a cross-aged design which involves in depth interview of 200 farmers in four selected states of the zone. The outcome is that climate change awareness in the zone is very low. The climate change events identified are rapid desertification, excessive heat and drought. The consequence is that most farmers lost farmlands and agricultural products to these climate change events. Also most of the farmers who are youths were rendered redundant due to the negative impact of these climate events on crops and agriculture. Consequently they engage in alternative activities like menial jobs, while some engage in criminal activities like drug addiction, theft, political thugery, armed robbery, kidnapping and terrorism. They become ready tools for recruitment by Boko-Haram terrorists who are active in the area. It is recommended that massive enlightenment and effective mitigation program should be conducted, youth who are not in school should be convinced to embrace education. Also measures and projects to re-engage the youths back to agriculture should be promoted.
\end{abstract}

Keywords: Climate variability, consequences, crime, insurgency, Nigeria

\section{Introduction}

Gaping ozone holes, collapsing ice sheets, rising temperatures, aboriginal villages swept away by flood and mudslides, villages and communities overtaken by desert encroachment, these and other disturbing accounts show that rapid climate change is here with us, (Smith, Stone and Fahrenramp- Uppenbrink, 2002, Hassan, 2012). At the center of climate variability discourse is how the dynamic behavior of the atmosphere and the oceans contribute to the weather patterns that have affected much of the world since the late $20^{\text {th }}$ century.

The variability in weather patterns have been felt in Africa and other parts of the world in varying manifestations and degree. In some parts of the world, it is the rapid melting of the Arctic ice cap, changes in Arctic seabird populations or threat to the polar bears. In other parts, it is unexpected heat wave, drought, rising sea levels, unprecedented rainfall, mudslides and flood disasters. In recent times, various parts of the world had witnessed these trends. For instance the Hurricane Katrina in New Orleans, USA in 2005, Fukushima flood nuclear disaster in Japan in 2011, the floods in China, India, Pakistan and Bangladesh, and also excessive rainfall and flood in Nigeria in 2012, the excessive heat in Russia in 2011, increasing drought and rapid desert encroachment in Chad, Niger and Nigeria, and even the drought in some parts of the U.S in 2012, (Mayumi, 2011, Newzealand Herald, 2011, Willie, 2005).

These unpredictable weather conditions tremendously affect agricultural activities in several negative ways especially in Nigeria, thus leading to lost of arable land and crops which in turn create total despondency and frustration among the agricultural population, mostly made up of youths. The curious coincidence however is that in Nigeria, especially within the Northeast zone, crop failures, and loss of farmlands occasioned by the impact of climate variability coincides with the rise in various criminal activities like the Boko Haram terrorist activities, armed robbery, kidnapping, bank robbery, etc. It became necessary to therefore investigate a possible correlation between the two social variables.

The outcome shows that Nigeria is a largely agricultural society with over $70 \%$ of her population mostly youth and women rudimentarily engaging in this sector. However, the negative impacts of climate change have led to massive crop 
failure and lose of farm lands. The tendency therefore is that most of the youths who normally engage or could engage in agriculture are made redundant while others abandon the endeavor. This is made worse by the gross insensitivity and neglect of the government to her social obligations to the citizens. Consequently, most of the youth migrate to the urban centre in search of non existing jobs, some took to menial jobs like petty trading, cobbler and shoe shining, commercial motorcyclist, bus drivers and conductors etc. Generally however, most of the youths who hitherto would have been actively engaged in agriculture become very vulnerable and engage in various criminal activities. This may partly explain the rise in criminal activities and insecurity in the Northeast zone of Nigeria.

\section{Theoretical Issues, Impacts of Climate Variability}

Most scholars accept the phenomenon of climate variability however, there are contentions as to the cause, capacity and possible dimensions. Some scholars argue that climate variability is mostly due to complex natural sequence which may be difficult to isolate, some assert that it is attributable to the excessive emission of greenhouse gases which heat up the ozone layer, while others argue that it may be wrong to attribute the cause of climate variability to a single factor.

According to Panofsky $(1956,2010)$ temperature, wind, rainfall and other characteristics of the whether fluctuate on scales of time, ranging from a fraction of a second to millions of years. While we know about variation on smaller time scales, human history is not long enough to permit certainty about variations with periods of about 10,000 years. He also assert that climate variations occur in all scales of time and are not due to a single cause, hence there are many possible causes and it is difficult to dispose the importance of any single effect.

Spencer, (2006) further argues that there are good reasons to distrust climate model projections of future global warming. According to him, the supposed scientific consensus that mankind is very likely to blame for recent global warmth is mostly a statement of faith made from a position of relative ignorance about natural variability in the climate system. Moritz, Blitz and Steig, (2002) also noted that the pattern of recent warming observed in the Arctic, exhibits both polar amplification and a strong relation with trends in the Arctic oscillation mode of atmospheric circulation. They further argued that though Paleo-climatic analysis indicate that Arctic surface temperatures were higher during the $20^{\text {th }}$ century than the preceding few centuries, polar amplification has been a common feature of the past, and Paleo-climate evidence for Holocene variations in the Arctic oscillation is mixed.

Despite the seeming skepticism by these scholars, most scientists and environmentalists attribute the major cause of climate variability to the activities of man which culminates in an unprecedented atmospheric concentration of green house gases (GHG) which causes stratospheric ozone depletion, global warming, Arctic ice shrinking and other consequences, (Graff, 2007, Valsson, 2007, USGS, 2005, Smith, Stone, Fahrenkamp, 2002, UNFCC, 2012, Figueres, 2012). There is also a general consensus and overwhelming evidence on the reality and impact of climate variability in almost all parts of the world whatever may be the cause.

According to the United Nations Framework Convention on Climate Change, (UNFCC), climate change is a complex problem which although environmental in nature, has consequences for all spheres of existence on our planet, (UNFCC, 2012). For the first time in recorded history, the North-west passage was ice free all the way from the Pacific to the Atlantic. Indeed, the Arctic ice caps in 2007 was less through melting, 10times the recent annual average, which amounts to an area greater than two countries combined (Graff, 2007). Global warming has rendered the Arctic more accessible than ever and made the Arctic to witness rapid transformation. According to Graff, (2007), the ice cap which floats atop much of the Arctic ocean is at least $25 \%$ smaller than it was 30 years ago. As the ice turns into water, the shrinkage is accelerating faster than climate models ever predicted. Graff further asserted that on August 28, 2007, satellite images analysis by the University of Colorado Snow and Ice Center revealed that the Arctic ice cap was already $10 \%$ smaller than at its previous record minimum in September, 2005. Trausti Valson of environmental planning at the University of Iceland also noted that Arctic warming has become a self propelling process that could leave the Arctic ocean ice free in summer by 2040 .

In recent times, there is credible evidence about the continuous impact of climate change. In August 2012, the United States National Snow and Ice Data Center reported that the extent of ice cover on the Arctic had shrunk by 186,000 sq miles compared to only five years ago, (Figueres, 2012). This will certainly disrupt the lives of those living in the Arctic region and the entire biodiversity of the area, with alarming potential consequences on ocean currents circulating the globe. Figueres, the head of UNFCC confirmed that it was observed in January that the warming temperature had enormous effects on the Antarctica with huge pieces of sea ice breaking off, triggering a shrinking of land based ice faster than had been anticipated by glaciologists, (Figueres, 2012).

Since what happens in Antarctica does not stay in Antarctica, there is a direct and proven correlation between ice melt and rising sea levels around the world, thus leading to floods, mudslides and tsunamis across the world. In August, 
2005, the United States of America experienced hurricane Katrina, one of the deadliest and most destructive Atlantic hurricane in the US since 1928. At least 1833 people died and about \$81billion worth of property damaged. The most affected States were, New Orleans, South Florida, Louisiana and the Mississippi Beachfronts, (Rappaport ed, 2008, Swanson, Dan, Marshal, 2006, Willie, 2005). Another recent manifestation is the super storm hurricane Sandy which swept through Haiti, the Caribbean and the East Coast of the United States from $28^{\text {th }}-30^{\text {th }}$ of October, 2012. The super storm affected over 50million people, killed over 100 people and led to the closure of schools, businesses, transportation and the closure of the stock market for two consecutive days since 1886 due to weather. The effect of the storm was so severe that the President, Barack Obama declared State of emergency in seven most affected States, (Bbc World News Oct, 2012; The Wall street Journal, Oct. 29, 2012; Washington Post, Oct. 29, 2012). The live of over 50million people who live in low lying Island States of the World are also directly threatened by the effects of melting ice. For instance, on the Island of Fiji, families are relocating to dryer higher lands because of rise in sea level and flooding. It got so bad that the former President of the Maldives sought but failed to get another country that would accept the entire population of the Maldives as climate refugees. In deed current projections by UNFCC estimates that between 26 - 30 years, there could be between 100 and 200 million climate refugees in the world, (Figueres, 2012).

Kern, (2002) further noted that the inevitability of shrinking ice on the Arctic ocean means hard times for polar bears and a threat to an indigenous way of life. Indeed a study by the United States Geological Survey (USGS, 2007) predicts, that shrinking sea ice will mean a two-third reduction in the population of polar bears by mid century. Croxall, Trathan, and Murphy, (2002) also linked the recent changes in Arctic seabird populations to the direct and indirect responses to regional climate change.

\section{Climate Variability Impact in Nigeria}

Nigeria like any other country in the world has been experiencing frequent unpredictable climate over some period of time, especially within the last 20years. Such unpredictability are manifest in excessive flooding, increased aridity, dwindling flow of the Niger basin and intensive desert encroachment, (NCF, 2012). The Northern part of the country, specifically the core desert frontline states of Kebbi, Sokoto, Zamfara, Katsina, Jigawa, Yobe, Adamawa, Gombe, Kano, Bauchi, and Borno have been witnessing increasing desert encroachment (Federal Ministry of Environment, 2012). According to experts, the pace of desert encroachment has been faster than predicted in recent times. The Federal Ministry of Environment in Nigeria posits that the current rate of desert encroachment into Nigeria is $0.6 \mathrm{~km}$ per annum, (FME, 2012). However, other non government experts and inhabitants of the area put the rate at about 20-30 kilometers per annum, (Dingyadi, 2012).

The natural consequences are dwindling farmlands, scotching heat, drought and general water scarcity. The major impact however is on agriculture, square kilometers of hitherto arable lands, crops and economic trees are lost to the desert. According to Dingyadi, (2012), over 154, 725 people in 5 frontline states lost their farm lands within 7 years. In deed Sokoto and Kebbi state alone lost over 145 and 170 kilometers of their landmass to the devastating effect of the desert in less than 5 years. Consequently, most of the farmers in these areas who are predominantly youths are despondent and frustrated. In reaction, most of them abandon farming for alternative activities.

In the south of Nigeria, the heat and warmth experienced during the dry season especially in 2009 and 2010 was very severe and more prolonged than usual. The seasonal periods were also very unpredictable and there were floods in Lagos and Ibadan. The situation of Lagos is worrisome. The organizational for Economic Cooperation and Development, France stated in a study that Lagos was at a risk of being submerged in the next 50 years. According to the report, in the $20^{\text {th }}$ Century, sea level rose by an estimated 17 centimeters. However, conservative global mean projection for sea level rise between 1990 and 2080 ranges from 23-34 centimeters. They further explained that oceans which have been absorbing $80 \%$ of the temperature increase attributable to global warming are expanding as ice sheets in the North and South poles melt. These events lead to rise in sea levels and catastrophic flooding of coastal cities (OECD, Report in Omegoh, 2012).

In 2012, Nigeria experienced the worst kind of flooding ever since its existence that affected all the 36 states in the Federation, (Taiwo - Obalonye, 2012). The President of Nigeria declared a national emergency and gave N17.6bilion in assistance to the victims and relevant agencies. The rainy season was unusually excessive both in volume and duration and also Cameroon opened the faucets of the Lagbo Dam to discharge excess water. This led to massive flooding in most communities in Taraba, Adamawa, Benue, Kogi, Delta, Enugu, Anambra, Bayelsa, Cross River and other states (Una, Adaji and George, 2012; Taiwo - Obalonye, 2012; John, Folaranmi, Obi, 2012).

In Cross River State, several villages in seven local government areas were sacked by flood which led to devastation of infrastructure, loss of life and destruction of economic trees. In some areas, the flood submerged houses 
and farmlands, destroyed bridges, while domestic animals and wild life were buried in mudslides stretching over two kilometers, (Una 2012).

Since September, 2012, communities on the banks of River Benue in Adamawa, Taraba and Benue states have lost houses, property, livestock, farm crops land and over 200 lives to flood, (Adaji and George, 2012). In Kogi state, houses were submerged, farmlands were lost and the major road linking southeast to Abuja was cut off by flood. In Anambra state the banks of River Niger also overflowed and flood took over most communities in Anam, Ogbaru, Otuocha and Onitsha. The destruction to yam a major farm produce in Anam made some farmers to commit suicide. In Delta State, the heavy rains and floods from the River Niger also submerged buildings, and destroyed lives and property in Asaba, Okoh, Ughelli and other communities. Also, similar situations were reported in Enugu and River states. Already massive food scarcity and hunger is predicted in 2013 by the Nigeria Minister of Environment (John, 2012).

It is important to note that despite the visible impacts of climate variability in Nigeria, not much attention is given to climate change issues. The Green House Gas (GHG) inventory data of UNFCC shows that the only available report from Nigeria was in 1994; (UNFCC, 2012). Therefore, GHG data on Nigeria from 1994 to 2016 is not available. However, the 1994 report indicates that total GHG emission was 114815.8 while carbon dioxide $\mathrm{CO}_{2}$ emission was $63.11 \%$. The sector responsible for the highest emission in the Country was energy.

\section{Methodology}

This study aimed at investigating the impact of climate variability on agriculture and the consequences on the high rate of criminal activity in the Northeast zone of Nigeria. The Northeast zone is made up of states like Borno, Yobe, Adamawa, Bauchi and Gombe. The area is made up of mostly Hausas, Kanuri and some indigenous populations. The predominant religion is Islam and some of the States have boundaries with Chad and Northern Cameroon. The Boko Haram religious terrorist organization began in Borno in this zone and spread to other parts of the North. The farmers in this zone engage in cereal and livestock farming.

The study is descriptive in nature and reflects a cross-aged design, involving the collection of qualitative data from in depth interview of 200 purposively selected farmers and 16 key informants in four states of the Northeast zone. Data was also collected from observational methods. The States are Borno, Yobe, Adamawa and Bauchi. The selection is purposively based on the States with the highest rate of crime and Boko Haram activities, also they make up the North East of Nigeria. A state of emergency was proclaimed in three of these states because of the activities of terrorists and criminals. The principal instruments adopted are desk reviews, in-depth interviews, participant observation and key informant interviews with 16 community leaders.

The data was analyzed for content through an inductive process to identify the level of awareness, manifestation, impact and consequences of climate change on high rate of criminal activity in the affected zone.

\section{Data Collection Instruments}

\subsection{In-depth interview (IDI)}

The primary instrument for this study is the in-depth interview. The in-depth interview was conducted with 200 purposively selected farmers from the four selected States of Borno, Yobe, Adamawa and Bauchi. The four States were randomly selected from the seven states of the Northeast region. Using the local government delineation within each state, two local governments were randomly selected from each state Also care was taken to ensure that none of the local government is within the frontline of the battle against Boko haram insurgency. The criteria for selection of the respondents are that they are farmers and had farmed and resided in the locality for at least ten years. Therefore, Fifty (50) farmers each were randomly selected and interviewed from each State, $(50 \times 4=200)$. The age interval of the interviewees is from 15 years and above. The lower boundary of 15 years was chosen because at that age, young people in Nigeria especially in the rural areas has started being very active in the farms. On the other hand, the age range accounts for most criminal activity in Nigeria.

The demographics of the respondents showed that adult males were $50 \%$ (100), adult females $20 \%$ (40), male and female youth $30 \%(60)$. The population of female respondents is the lowest because it is difficult to have access to the females because of religious restrictions. The population of the selected States were made up of Hausa Fulani's, Kanuri's and other minority Hausa groups. The religion is mostly Islamic with minority Christians and traditional African religious worshippers. The interview was conducted with a carefully constructed in-depth interview schedule which contained about fifteen core questions and probes around climate change awareness/knowledge, climate change impact and 
experiences, consequences for agriculture and implications for crime and insurgency within the selected areas. The study was conducted by the researcher and four trained research assistants who came from the locality to overcome the challenge of language and accessibility. Everyone in the research team understands Hausa language which is the general language in the study area. The interviews were conducted in the local Hausa language and later transcribed and translated into English language using the gold standard translation method.

The key informant interview was conducted with 16 respondents made up of four community leaders each from the selected four States. The key informants were generally knowledgeable, experienced and have distinguished themselves within the area either as lead farmers or culture and political bearers. The information elicited centred around the subject matter and meant to get more detailed information. The interview took about forty to sixty minutes in each case.

The desk review was based on available existing literature from libraries, journals, periodicals and official reports on the subject matter. The participant observation was useful because the researcher and all the research assistants had resided in the locality for up to ten (10) years and had observed first hand some of the climate change manifestations. The participant observation adopted the Rapid Rural Appraisal (RRA) method which involved transect walks, identification and inspection of farmlands to effectively observe and document climate change impacts within the area.

\subsection{Study Propositions/Objectives:}

The study has the following operational propositions:

- Community members in the selected States are less likely to have high level of knowledge and awareness about climate change

- Climate change manifestations has direct negative impact/effect on agriculture in Northeast Nigeria

- Failure of agriculture occasioned by climate change impact is positively related to high level of crime and insurgency in Northeast Nigeria.

The objectives of the study are to:

- Know the Knowledge/awareness level of the respondents on the phenomenon of climate change

- Examine the manifestation of climate change, impacts and consequences on agriculture in the areas of study

- Establish possible relationship between the negative impacts of climate change on agriculture and high rate of crime and insurgency in Northeast Nigeria

Finally, the study sets out to contribute to a framework for raising the awareness of key stakeholders and decision makers on the climate change phenomenon with a few to stimulating discussion around the social implications of climate change especially its possible relationship to crime and insurgency in research and policy circles.

\section{Presentation of Results}

Data from In-depth interview: This is the primary data collection instrument for the study and the outcome is presented on the basis of relevant themes. The interview data was divided into four sections, A-D.

\subsection{Knowledge /awareness of climate change phenomenon:}

This was interrogated using the following criteria: Respondents were asked if they have ever heard the concept of climate change, they were asked if they understood what constitute climate change, finally they were asked to indicate the subjects that constitute climate change.

In Borno, the result shows that $90 \%$ of the respondents do not have any knowledge of climate change and are not aware of the concept or phenomenon of climate change while only $10 \%$ had limited knowledge of the phenomenon. In Adamawa State, $85 \%$ do not have knowledge of climate change and are not aware of the concept and phenomenon of climate change while only 15\%have limited knowledge of the concept. In Yobe State, 89\% do not have any knowledge of climate and are not aware of the concept while only 11\% have limited knowledge of the concept. In Bauchi State, 95\% do not have any knowledge of climate change and are not aware of the concept while only $5 \%$ stated that they are aware of the concept. The respondents were further asked the medium through which they got the knowledge of climate change. Majority of them indicated that they heard about it through radio, specifically the Bbc Hausa service. This is supported by direct quotations from both the IDI and the KII:

I have not heard about climate change before, to me that is 'dogo turanchi'(long grammer), I am just a farmer, (KII male, 47years, Borno) 
I do not know what you mean by climate change, I spend most of my time in my farm, especially now when the farms are not encouraging (KII male, 50years, Yobe)

As you can see am a farmer, my major concern is my farm, if what you are saying will help me in my farm, I will like to know about it (IDI male, 45 Bauchi)

\subsection{Changing weather conditions/Climate change manifestations:}

This was interrogated using the following criteria: experience of weather regularity/irregularity; shrinking or shortage of rainfall, drought, desert encroachment/desertification/ loss of farmlands, dry/scotching hotness, shrinking of the lake chad.

The response showed that all the respondents (95\%) have experienced constant irregularity of the weather especially within the last nine years. In Borno, Yobe, Bauchi and Adamawa, 95\% have experienced drought and shortage of rainfall, while the remaining $5 \%$ could not clearly indicate. On desert encroachment/ desertification/loss of farmlands, $96 \%$ of respondents from the States especially in Borno Yobe and Bauchi indicated this feature. For dry/scotching hotness or increased temperature, all the respondents(100\%) from the States indicated this experience. In Borno State, (98\%) of the respondents stated that the lake chad had been progressively shrinking. The respondents were asked whether the above features are related or are attributed to the effects of climate change and none of them $(0 \%)$ could confirm this relationship or linkage.

Direct quotations from IDI and KII:

Yes, sometimes the weather can slightly change, but I have not experienced the magnitude of weather change that we are experiencing today in the past six years (KII male, 40years, Borno)

Last year the rain came, we went to the farm only for the rain to seize, so we do not even know anymore when actually the dry season stops and when the rain actually starts (KII male, Adamawa)

In the Northeast, we are used to the hot temperature, but the one we are experiencing now is extreme hotness, the temperature is very high, much hotter than it used to before (KII male, 53years, Yobe)

\subsection{Impacts/effects on agriculture:}

The respondents were asked about the impact and consequences of the above features of climate change on agriculture in the States; $90 \%$ of the respondents especially in Borno, Yobe and Bauchi stated that massive desert encroachment has led to massive loss of farmland and in some cases, residential land. All the respondents (99\%) stated that increasing drought, shortage of rainfall leads to crop failure and death of livestock and ruminants. About $80 \%$ respondents also stated that there has been increased manifestation of strange pests and diseases which kill crops like maize, millets and tomatoes. In Borno State, the respondents (98\%) indicated that the shrinking of the lake chad had strongly affected fishing and reduced water for farming and livestock. Generally, $97 \%$ of youth stated that the effects and consequences on agriculture act as huge disincentive to agriculture while $75 \%$ of the adult respondents stated the same.

Direct quotations from KII and KII:

Before now, that is about eight years ago, my farm was very huge, now most of them have been taking over by the desert, I feel helpless (IDI male, 52years, Borno)

I do not know what to call this; these days there are new pest sand diseases that affect and kill our crops. Some of them are like maggots and they eat up crops like maize, millet and tomatoes. (KII male, 40years Adamawa)

Every year, the rain keeps reducing and the drought continues to increase. There is less water for both the crops and the livestock, you know, we depend on natural rainfall for both our crops and animals (IDI male, 50years, Bauchi)

\subsection{Consequences for crime and insurgency:}

The respondents were asked about the consequences of the above effects of climate change on crime and insurgency especially on the youth. They were asked the extent to which the youth are still interested in farming, the effects of failure in agriculture occasioned by climate change on youth participation in agriculture, whether the disincentive in agriculture by the youth has made them vulnerable for recruitment by the Boko haram terrorist organization, and whether it has also 
made the youth to be more disposed to engaging in other criminal activities. The outcome showed that in Borno State, 95\% of respondents , in Yobe, 90\%,in Bauchi, 90\% and in Adamawa, $85 \%$ stated that the youth are no longer interested in farming due to the failure of agriculture occasioned by climate change. Generally, $60 \%$ of the respondents stated that disincentive in agriculture by the youth has made them vulnerable for recruitment by the Boko haram and has also made them to engage more in other criminal activities rather than farming.

The data from the secondary instrument, the Key Informant Interview (KII) of sixteen respondents was also based on the four major planks as above. The outcome which largely confirms the results from the in-depth interview was used to complement the IDI results using direct quotations. Same is applicable to the participant observation. The desk review was mostly used in building the relevant information and literature for the study. Direct Quotations from IDI and KII:

\begin{abstract}
When we were young, we enjoyed following our parents to farm, it was part of the tradition and everybody enjoyed it, but today it is not the same, the young ones are no longer happy to farm(IDI male, 58years, Borno)

The bad experience we are going through in our farms is discouraging, it is just that we have no choice but to continue with the farms so we can eat otherwise hunger will kill us, but the young ones are no longer interested, some of them are joining Boko haram and doing other bad things(KII male, 60years, Bauchi)
\end{abstract}

I have some of my friends who joined Boko haram out of frustration, like Shehu and Musa. I refused to join because I do not like their style, I joined the civilian JTF( the local vigilante that assist the military) instead. (KII male, 21years, Borno)

Most of the young ones are actually angry with the government for not taking care of them. They no longer engage in farm because they see it as waste of time. We have been trying to talk to them, but some join bad groups and even Boko haram (IDI male, 54 years, Adamawa)

\title{
7. Discussion and Analysis of Results
}

According to the Intergovernmental Panel on Climate Change (IPCC) $4^{\text {th }}$ assessment report, warming of the climate system is unequivocal and Green House Gas (GHG) emissions would induce many changes in the global climate system during the $21^{\text {st }}$ century that would be larger than those observed in the $20^{\text {th }}$ century. The report further stated that Africa has been identified as being especially vulnerable because of low adaptive capacity and projected climate change impacts.

Developing countries are also more vulnerable to climate change due to the predominance of rain fed agriculture, the scarcity of capital for adaptation measures, their warmer baseline climates and their heightened exposure to extreme weather events, (Fischer G, Stah M, Tubiedo F.N and Van Velhuizen H, 2005; Nnamchi and Ozor, 2009).

The first strand of the study which focused on the knowledge/ awareness of climate change showed that generally and on the average, $90 \%$ of the respondents across the four States do not have any knowledge of climate change and are not aware of the concept, while only $10 \%$ had limited knowledge of the phenomenon. The very low outcome is very critical because of possible implications for mitigation and adaptation efforts. The low level of awareness may also be related to the very low general literacy level especially among farmers in the area.

This result though from a study of the Northeast Nigeria, aligns with the outcome of a study conducted in the Niger Delta region of Nigeria by Nzeadibe T.C, Egbule, C.L, Chukwuone, N.A and Agu, V.C (2011). The Study which looked at climate change awareness and adaptation in the Niger delta region used a multi stage sampling technique to interview 200 heads of farming households in Cross River, Rivers and Delta State. The result indicated that the level of awareness of local communities of climate change was still very low in the Niger Delta region; about $60 \%$ know little or nothing about climate change and its impacts. The only difference in the two results is the level or magnitude of ignorance of climate change in the Northeast and Niger Delta region of Nigeria, (90\% to 60\%). The media especially radio played a major role among the farmers in both study that indicated individual awareness, but while for this study it is a foreign media, the Bbc, for the Niger Delta study it was the local Media.

The study by Odjugo and Ovuyovwiroye (2013) also validated our finding. The study which was on the analysis of climate change awareness in Nigeria involved a survey of 1200 sample of respondents from the tropical maritime and the tropical continental climate zones of Nigeria; made up of Lagos, Rivers, Imo State (mT) and Yobe Zamfara, Niger and Adamawa State (CT). The results showed that while $25 \%$ have no knowledge of climate change, $52 \%$ have little or limited knowledge of climate change.

Another study by Oruonye, E.A (2011) further confirms the outcome of this study. The study which was an assessment of the level of awareness of the effects of climate change among students of tertiary institutions in Jalingo 
Taraba state Nigeria, adopted a descriptive survey design using questionnaire instrument with 225 Sample. The result showed that $15 \%$ have never heard about climate change at all. However among $81 \%$ who have heard about climate change, $89 \%$ do not know what climate change is all about, its causes, effects and possible adaptive measures. Therefore based on the outcome of this study and others, it is safe to conclude that in Nigeria, the knowledge and awareness of climate change is generally low.

The second proposition of the study is that climate change manifestation has direct negative impact/effects on agriculture. The objective is to examine the manifestation of climate change, impacts and consequences on agriculture in the areas of study. In Borno State, there are agricultural communities like, Biu, Konduga, Askari/Uba, Bama, Kukawa, Mafa, Jere, Abadam, Gozza and Hawul. In Adamawa State, some of the agricultural communities are, Ganye, Garkida,Gella Betso, Gombi,Girei, Kalaa, Maiha, Mubi, Mbalang, Buyuk, Tongo,Demsa and Imburu. These communities mostly produce grains like millet, soghurn, beans, groundnut, guinea corn and livestock. Some parts of Adamawa also produce yam. The findings showed that the respondents have experienced constant irregularity of the weather within the last nine years, drought and shortage of rainfall, desert encroachment/desertification/loss of farmlands, dry/scotching hotness and increased temperature and the progressive shrinking of the Lake Chad within the study area. The data collected shows that the variability in weather had tremendous impact on agriculture in the Northeastern zone of Nigeria. These climate change features were further found to have massive negative consequences for agriculture in the region. One of the farmers in Borno gave a bitter narration of how his home and farmland was eventually lost to the desert in 2011. The farmers also stated that they recently experienced more dry scotching hotness of the sun than was the case in previous times, a situation which negatively affected their farm crops. A community leader in Misau, Bauchi State, Mallam Yakubu (not real name) strongly complained about the scarcity of water for both human consumption and grazing of crops and livestock. Indeed, the researcher observed that only one old well serves as the only source of water in one of the communities in the area. In Adamawa State, similar outcomes were found in agricultural communities like Buyuk, Tongo, Mubi, Imburu Mbalang and Demsa. For instance in Mubi, the beans cultivation has very much reduced in recent years. Also in Bama, Borno State, the lack of water has led to unwarranted death of livestock and low crop yield. In Bama, a community leader, Mallam Yunusa Bama stated that:

most farmers in the area have been going through severe frustration and heart break because they invest so much in the farms and come out with nothing (KII male, 57years, Borno).

This outcome is in conformity with some earlier studies in Africa and Nigeria which established and highlighted the negative impacts of climate change on agriculture. According to Speranza (2010), recent research has noted the impacts of climate change on agriculture and natural resources management in countries of Africa, Asia and Latin America. Studies by Rukevwe $(2008)$ Ojugo $(2009,2010)$ Nzeadibe et al, (2011) in Nigeria, supports the above finding. Also scholars like Ayinde, Muchie and Olatunji, (2011) in their study on the effects of climate change on agricultural productivity in Nigeria noted that climate fluctuation is putting Nigeria's agricultural system under serious threat and stress. They established that agricultural productivity is higher between 1981 and 1995 and much lower between 2006 and 2000.

According to IPCC in Umar and Ozohu, (2015), agricultural, production and food supply in many African countries and regions are likely to be severely compromised by climate change. It was reported that under current agricultural production systems in Africa, a $2^{\circ} \mathrm{C}$ increase in temperature could result in 12 million people at risk of hunger as a result of crop failure by 2050. Umar and Ozohu (2015) further reported that in Africa, droughts can have severe impacts on livestock mortality. According to these scholars, shift in rainfall patterns is very detrimental to rain fed crops production which occupies more than $90 \%$ of crops/farms in Nigeria. Africa is also predicted to see an increase in crop pests and diseases due to unusual migration of pests and crop diseases in response to climate variations. Dhanush (2015) further confirmed that climate change will bring greater risk of pests and diseases to African agricultural systems, affecting crops, livestock and fishery productivity. This is in line with the findings of this study which indicated that $80 \%$ of the respondents stated an increased manifestation of strange pests and diseases which kill crops like maize, millets and tomatoes. One of the KII participant puts it thus;

I do not know what to call this; these days there are new pest sand diseases that affect and kill our crops. Some of them are like maggots and they eat up crops like maize, millet and tomatoes. (KII male, 40years Adamawa)

Also, $98 \%$ of the respondents in this study stated that the Lake Chad whose water once supported vast swathes of farming and grazing in the northeast region has been shrinking. This finding is supported by Eichelberger, (2014) in a study which noted that Lake Chad has lost more than $90 \%$ of its original size due mostly to recurrent droughts. 
In this study, $90 \%$ of the respondents further noted that desert encroachment in the Northeast has led to massive loss of farmland and in some cases, residential land. This is in line with the assertion of Nigerian Federal Ministry of Environment (FME, 2012) and Dambazzau, (2014) as contained in a Harvard international review which stated that Nigeria is estimated to be losing about 1400 square miles of land to decertification in the Northeast especially Borno and Yobe the home of Boko haram; which has led to land degradation, water scarcity, loss of vegetation and reduced agricultural productivity. Most of these previous studies supported the finding in this study, but none of them was able to establish a link between the negative effects of climate change on agriculture and high level of crime and insurgency. This is what the fourth proposition of this study intends to achieve.

The fourth proposition stated that failure of agriculture occasioned by climate change impact is positively related to high level of crime and insurgency in Northeast Nigeria. The findings showed that on the average, $90 \%$ of the youth are no longer interested in farming, and $80 \%$ stated that the inherent disincentive to agriculture by the youth has made them to engage in other criminal activity rather than farming and has made them to be vulnerable for recruitment by Boko haram. In the Northeast, most (80\%) of the respondents indicated that the huge loss of farmlands, crop failure and frustration incurred by the farmers in the area have made most of them especially the youth to abandon farming and engage in alternative activities like commercial motorcyclist (achaba) cobblers, petty trading, security guards (mai-gadi) and hawking water (mai-ruwa). However, more than half, $(60 \%)$ indicated that most of the youths disengaged from agriculture are involved in criminal activities like armed robbery, drug abuse, political thugery and terrorism like the Boko Haram group which is very active in this zone. It is further observed that in this zone, especially Bauchi, Yobe and Borno, there are so many youths (60\%) who are not in school, in the farm or in any job. According to a community leader in Bidir village, Katagum Bauchi state,

most of the youths have abandoned farming because most of the farm lands have been lost to the desert, and farming is no longer attractive or lucrative, and when somebody is idle, he can easily engage in criminal activities (KII male, 60years, Bauchi).

Another community leader in one predominantly Moslem quarter in Bauchi town also stated that most of their youths who are not engaged are now joining bad groups especially the Boko Haram. According to him, "The youths are hungry, disgruntled and unhappy, they believe that the politicians have failed them." This situation was also observed in the cause of the study. Most of those interviewed in Borno State, (60\%) stated that the Boko-haram people were attractive to the youth because they give them money and also provide for them. Among the youth interviewed, most of them (65\%) stated that some of their friends joined the Boko-haram sect because they have nothing else to do. When asked whether it is more of appeal to perceived higher religious calling than lack of something to do, most of them (64\%) stated that the religious thing is there, but it is more of poverty and lack of something to do.

The socioeconomics of the Northeast region according to Mailafiah (2012), and the Nigeria National Bureau of Statistics (NBS), shows that in Nigeria, more than $60 \%$ live below the poverty line and $54 \%$ of the youth are unemployed. Borno and the Northeast comprise some of the most impoverished regions in Nigeria with the incidence of absolute poverty exceeding $70 \%$ mark. Poverty in Borno and other parts of the Northeast is compromised by ecological factors. Illiteracy, lack of educational opportunities and youth unemployment in the Northeast are a major stumbling block to social economic progress. According to Eichelberger (2014), drought, population explosion and poverty are aggravating conflict in Nigeria and climate change will likely add fuel to the fire. Vanda Felbab-Brown, (in Eichelberger) an expert in insurgency at the Brookings Institution stated that much of the conflict between Christians and Moslems (in the Northeast of Nigeria) is about land and access to water, but Boko haram is tapping and inflaming those sentiments. Okoriyodo,(in Eichelberger) a Nigerian security expert also asserted that young Moslem Fulani's in the Northeast will be sucked into the growing Boko haram insurgency as the Nigeria's farmer- herdsmen conflict heats up and young people are mostly pushed to the wall due to the frustrations from crop failures. Eichelberger (2014) also asserted that it has become easy for Boko haram to recruit Northern Nigerians because people are already aggrieved, hopeless and depressed because they are losing their source of livelihood partly to climate change. A condition which the French Sociologist Emile Durkheim aptly identified as a state of anomie, (Ritzer 2008).

Eichelberger (2014) further stated that Boko haram has slaughtered over 5000 people. The terror group whose name means 'western education is sin' though staffs its members from mosques and Islamic schools, economic hardship also helps drive recruitment. Poverty and unemployment in the Northeast have reinforced the Boko haram narrative that says the government has been corrupt by western values. Those who sign up for terrorism are motivated as much by economics as by the groups Islamic rhetoric. Also Maku Labaran, former Nigerian minister for information stated that poverty due partly to crop failures in the North, creates a conducive environment for terrorism to prosper (Eichelberger, 
2014). Dambazzau (2014) finally asserted that the States in the Northeast are lacking critical infrastructures, unemployment is extremely high, the vast majority of people experience extreme poverty, enabling Boko haram to easily recruit people. A participant in one of the interviews puts it this way:

\begin{abstract}
Most of the young ones are actually angry with the government for not taking care of them. They no longer engage in farm they see it as waste of time. We have been trying to talk to them, but some join bad groups and even Boko haram (IDI male, 54years. Adamawa)
\end{abstract}

\title{
8. Conclusion
}

Though it is difficult as is the case with other variables to establish a direct relationship between climate change and crime, it could be deduced on the basis of available data that the impact of climate change, especially on agriculture, have both direct and indirect implications for the high level of criminal activity in the Northeast of Nigeria. In Nigeria, about $70 \%$ of the 162 million population, (NPC, 2006, UNDP, 2011) engage in agriculture, and most of the farm hands are made up of the youth. Also more than half of the population are poor and cannot afford up to $1 \$$ per day, especially in the rural areas.

The rapidity of climate variation that has been witnessed in the last ten years in this zone has resulted in huge impacts on the environment, and especially agriculture. These impacts were manifest in massive desert encroachment on farmlands droughts, crop and livestock failure in the Northeast. Consequently, the youths who hitherto engaged in agriculture in frustration abandon the farms for other alternative activities. Some of them engage in menial jobs, commercial motorcyclist, night guard, petty trading and hawking of water. However, most of the youths engage in criminal activity like armed robbery, drug abuse, theft, rape and terrorist activity in most States of the Northeast especially Borno, Yobe, Bauchi and Adamawa.

In the Northeast zone, the consequences of climate change impact has made the youth to abandon agriculture and thus become vulnerable tools for the Boko Haram terrorists who easily recruit and use them for terrorist activities. In Nigeria, the above Northeast States are focal areas for Boko Haram activities which has become a huge national security issue for the Nation. Indeed the President of Nigeria confirmed that the activities of this group had led to massive lost of lives and property and caused fear among the citizens. According to him, the terrorists have attacked government buildings and personnel, killed innocent citizens and taken women and children as hostages. Consequently, a state of emergency was declared in Adamawa, Borno and Yobe States, (Omipitan,Amodu \& Folashade-Koyi,2013).

\section{Recommendations}

Public Enlightenment: The obvious fact is that most Nigerians, even among the educated are not quite aware of the concept of climate change. This is worst in the area of study especially when it comes to non literate rural farmers. Therefore, both the government and private organizations should ensure that climate change issues take first priority in media programs and activities. The aggressive enlightenment programs should be organized in both English and the local language like Hausa, Kanuri, Igbo, Fulfude, Yoruba etc. and targeted at both the rural youths and women.

It is also important to include climate change issues in the curriculum of both secondary and tertiary institutions in Nigeria. This will enable the young ones to be conversant with climate change issues early in life. The future belongs to these young ones, and they should be given the tools to effectively deal with it.

There should be effective climate change mitigation strategy pioneered by both government, private sector and community members. Specifically, in the North east zone and especially in areas that are not displaced, concrete and sustainable soil reclamation programs should be embarked upon. This should include aggressive tree planting, construction of shelter belts and wood lands. Water reservation sites should also be constituted for water reticulation and regular wetting of arable lands.

Since agriculture is the highest employer of labor in Nigeria, the government should spend more and do more to develop the sector. Improved seedlings, modern farming equipments, planting techniques and preservation methods should be introduced to farmers. The current rudimentary method of farming in Nigeria today should be gradually transformed to mechanized farming. Also interest-free credit facilities should be given to genuine farmers to enable them embark on commercial farming. Agricultural banks should be located in the rural areas close to the farmers and the procedure for accessing the credit facility should be simple to enable the farmers, easy access to the facility.

In the short term, the government should compensate genuine farmers who lost their crops through the impacts of climate change like desert encroachment and drought. Those of them who obtained loans to farm and lost these crops 
should be given a waiver. Also, programs and incentives should be given to the youth to encourage them to re-engage in agriculture, because the more the youth are engaged in agriculture, the more they are taken away from crime. Agriculture should be made attractive to the youth even when they are attending schools. Youth should not be allowed to remain idle. The various local governments in the zone should identify able but idle youths in their areas and either send them to school or to the farm, or both.

Generally, individuals should be oriented towards positive climate change adaptation attitudes and behavior like the use of few cars, less charcoal, fire wood, and generating sets. Also, the promotion of green environment should be encouraged.

\section{References}

Adaji, B. \& George, U. (2012). Flood pains of 3 States. The News Magazine. Independent Communications Network Limited, Vol. 39. No. 13 October 1. Ikeja,Lagos.

Ayinde, O.J\&Ozohu D.A (2015). Impact of climate change on agricultural production and food supply in Africa. International conference on latest trends in food, biological and ecological sciences, Dubai, October, 11-12

British Broadcasting Corporation, BBC, (2012) World News, May,28.London

Croxall, J.P, Trathan, P.N; \& Murphy, E.J. (2002). Environmental Change and Antarctic Seabird Population. Science, 30 August, Vol. 297 No. 5586.

Dambazzau, A (2014). Nigeria and her security challenges. Harvard International Review 35(4).Spring. hir.harvard.edu/Nigeria. Accessed 17-09-16

Dingyadi, F, (2012). Desert encroachment poor response on managing disasters. http://www.gamji.com. Retrieved 13 ${ }^{\text {th }}$ October, 2012.

Eichelberger, E, (2014).How environmental disaster is making Boko-haram violence worse. Mother Jones. www.motherjones,com/environment/2014/06/Nigeria

Fisher, G, Shah M, Tubiedo, F.N \&Vanvelhuizen, H, (2015). Socioeconomic and climate change impacts on agriculture: an integrated assessment 1990-2080. Phil Trans. R. Soc B360, 2067-2083

Federal Ministry of Environment, Nigeria (2012) Federal Government Launches GWSI Project to comb desert encroachment. All Africa. Com,September 11.

Figueres, C. (2012). The anthropology of climate change. Lecture,SwarthMoore college, Pennsylvania: 28th September.

Graff, J., (2007). Fight for the top of the world as global warning melts the Arctic Ice. Time Magazine October 1.

Hassan, B, (2012). Drought and desertification amelioration department Nigeria: Federal Ministry of Environment. http://allafrica.c om, Retrieved 13 ${ }^{\text {th }}$ October, 2012.

Intergovernmental Panel on Climate Change, IPCC, (2007). $4^{\text {th }}$ assessment report

John, T; Folaranmi, F. (2012). Flood: snakes invade Rivers community. Daily Sun Newspaper. The Sun Publishing Limited October, 5. Lagos.

Kerp, R.A, (2002). A Warmer arctic means change for all Science Vol 297, August, 30.

Mailafia, O, (2012). Conflict and insurgency in Nigeria. 247 Ureport. 247 Ureport.com Sept 20

Mayumi, N. (2011). Japan raises nuclear crisis seventy to highest Level. Reuters April, 12.

Moritz, E.R, Blitz, C.M. \& Steig, E.J. (2002). Dynamics of recent climate change in the Arctic. Science Vol. 297, August, 30.

Newzealand Herald, (2011). Japan's unfolding disasters bigger than Chernobyl" April, 2.

Nigeria Population Commission, NPC (2006). National Population Census, Nigeria. Nigeria: Abuja

Nigerian Conservative foundation, NCF (2012). Approach to climate Change. www.ncfnigeria.org. Retrieved 13 $3^{\text {th }}$ October, 2012.

Nnamchi, H.L. Ozor, N.O (2009).Climate change and the uncertainty facing farming communities in the middle belt region of West Afric a. $7^{\text {th }}$ International Science conference on the human dimension of global environmental change. Bonn: United Nations University, $26^{\text {th }}-1$ st May.

Nzeadibe, T. C, Egbule, C.L, Chukwuone, N.A, Agu, V.C. (2011). Climate change awareness and adaptation in the Niger Delta region. African Technology Policy Studies Network working Paper Series No 57. Nairobi

Omipidan, I, Amodu, T, Folasade-Koyi (2013). Enough is enough, as Jonathan slams Adamawa, Borno, Yobe with emergency rule. Daily Sun Newspapers. The Sun Publishers, May 15. Lagos

Odjugo, P.A, (2009).Quantifying the cost 0 climate change impact in Nigeria: emphasis on wind and rainstorms. Journal of Human Ecology 28(3) 93-101

Odjugo, P.A. (2010). Shifts in crops production as means of adaptation to climate change in the semi-arid region of Nigeria. Journal of Meteorological Climate Science 8 (1) 1-6

Odjugo, P.A \& Onuyovwiroye, (2013). Analysis of climate change awareness in Nigeria. Academic Journal vol. 8 (26). http://www/academic journals. org. DOI 10.5897/SRE, accessed 19-09-2016

Organization for Economic Cooperation and Development, (OECD) Report in Omegoh, C. (2012). Lagos may vanish in 50years. Daily Sun, October, 5.

Oruonye, E.A, (2011).An assessment of the level of awareness of the effects of tertiary institutions in Jalingo metropolis Taraba State Nigeria. Journal of Geography and Regional Planning, Vol.4 (9) pp513-517

Panofsky, H.A, (2010). Theories of climate change. Journal Weatherwise Version of Record, July, 08. 
Rappaport ed, (2008). Preliminary report for hurricane Andrew. National hurricane center,USA. retrieved April, 10.

Ritzer, G. (2008). Sociological Theory. Boston: Mcgraw-Hill Higher Education

Rukevwe, O.V. (2008). The science of climate change: implication for Africa. Journal of Arid Environment 7(1) 72-85

Smith, J., Stone R. \& Fahrenkamp - Uppernbrink, J. (2002). Science Journal Vol. 297 No 5586.

Spencer, R.W; (2006). How serious is the global warming threat Journal Society, 45-50.

Speranza, C.I. (2010). Resilient adaptation to climate change in African agriculture. Bonn Development Institute

Swanson, D.D; \& Marshal, B; (2005). Flash flood. Hurricane Katrina's inundation of New Orleans, August 29.

Taiwo - Obalonye, J; (2012). Jonathan approves N17.6bn for flood Victims. Daily Sun Newspaper. The Sun Publishing Limited. Lagos

Umar, O.J \& Ozohu, D.A.(2015). Impact of climate change on agricultural production and food supply in Africa. International Conference on latest trends in food biological and ecological sciences Dubai, UAE, Oct. 11-12

Una, E; (2012). Flood agony spreads. The News magazine. Independent Communications Network Limited. Vol. 39. Lagos.

Una, E. Adaji, B. \& George, U; (2012). Flood pains of 3 States. The News magazine. Independent Communications Network Limited, Vol. 39, October, 1. Lagos

United Nations Development Program, UNDP, (2011). National Human development report.

United Nations Framework Convention on Climate Change UNFCC (2012) Status of ratification of the Kyoto Protocol.

Valsson, T; (2007). Fight for the top of the world Times, October, 1.

Wallstreet Journal, (2012). Report on hurricane sandy. October 29.

Washington Post, (2012). Hurricane sandy report. October, 29-30

Willie, D. (2005). Hurricane katrina pulls its punches in New Orleans. National Geographic. August, 29. 